\title{
EFFECT OF PIPERONYL BUTOXIDE AND SILVER NITRATE ON DEGRADATION PATHWAYS OF N-OCTADECANE BY Fusarium sp. F092
}

\author{
Asep Hidayat ${ }^{* 1}$ and Sanro Tachibana ${ }^{2}$ \\ ${ }^{1}$ Research Institute on Fiber Technology of Plantation Forest, \\ Jl. Raya Bangkinang Kuok Km. 9, Bangkinang, Riau, 28401 - Indonesia \\ ${ }^{2}$ Department of Applied Bioscience, Faculty of Agriculture, Ehime University 3-5-7 \\ Tarumi, Matsuyama, Ehime, 790-8566 Japan
}

Received: 10 October 2014, Revised: 6 April 2016, Accepted: 20 April 2016

\begin{abstract}
EFFECT OF PIPERONYL BUTOXIDE AND SILVER NITRATE ON DEGRADATION PATHWAYS OF N-OCTADECANE BY Fusarium sp. F092. The aliphatic fraction is usually the largest component in crude oil. Its removal from oil contaminated fields has become an environmental priority and been considered useful for enhancing environmental recovery. Our previous studies reported the isolation of Fusarium sp. F092 based on its ability to degrade chrysene. F092 could also degrade crude oils and their aliphatic fractions. However, aliphatic degradation pathways in crude oil have not been clearly understood. The identification of aliphatic metabolite pathways using a representative compound $n$-octadecane was carried out in this study, as well as the effect of Piperonyl Butoxide $(\mathrm{PB})$ and Silver Nitrate $\left(\mathrm{AgNO}_{3}\right)$ on the degradation of n-octadecane and its metabolite. Fusarium sp. F092 had ability to break down n-octadecane from about 125 to $13 \mathrm{mg} \mathrm{L}^{-1}$ after 60 days incubation. During degradation, several metabolite products could be detected and identified to form carboxylic acid groups. By the addition of $\mathrm{PB}$ and $\mathrm{AgNO}_{3}$, inhibitor of monooxygenase and dioxygenase enzymes, Fusarium sp. F092 had ability to convert $n$-octadecane to form alkyl hydroperoxides via terminal oxidation pathway with involvement of a dioxygenase.
\end{abstract}

Keywords: n-Octadecane, aliphatic, biodegradation, metabolites product, enzymes, Fusarium sp. F092

PENGARUH PIPERONIL DAN PERAKNITRAT DALAM JALUR PENGURALANn-OKTADEKANA OLEH Fusarium sp. F092. Susunan senyawa yang paling besar terdapat di minyak mentah adalah senyawa alifatik. Remediasi senyawa alifatik pada areal terkontaminasi minyak mentah menjadi perhatian utama masalah lingkungan dan bisa menjadi tolak ukur dalam upaya pemulihan areal tercemar. Penelitian sebelumnya menemukan babwa jamur Fusarium sp. F092 mampu mengurai chrysene dan senyawa alifatik yang menjadi penyusun ceceran minyak mentah. Akan tetapi khusus untuk, penguraian senyawa alifatik, mekanisme jalur degradasi oleh F092 belum terungkeap secara jelas. Penelitian ini bertujuan untuk mengidentifikasi mekanisme degradasi senyawa alifatik dengan menggunakan satu senyawa tunggal alifatik, n-oktadekana berikut pengaruh pemberian Piperonyl Butoxide (PB) dan Perak Nitrat $\left(\mathrm{AgNO}_{3}\right)$ dalam penguraian n-oktadekana. Hasil penelitian menunjukkan bahwa Fusarium sp. F092 mampu mengurai n-oktadekana dari konsentrasi awal $125 \mathrm{mg} \mathrm{L}^{-1}$ menjadi $13 \mathrm{mg} \mathrm{L}^{-1}$ selama 60 hari masa inkubasi. Beberapa senyawa metabolit hasil penguraian dapat terdeteksi dan teridentifikasi sebagai kelompok senyawa asam karboksilat. Dengan penambahan PB dan AgNO3 sebagai penghambat aktivitas enzim dioxygenase dan monooxygenase, dapat diketabui babwa penguraian n-oktadekana oleh Fusarium sp. F092 diawali dengan merubah n-oktadekana menjadi alkyl bydroperoxides melalui jalur terminal oksidasi dengan melibatkan enzim dioxygenase.

Keywords: n-Oktadekana, alifatik, biodegradation, produk, metabolit, en₹im, Fusarium sp. F092

*Corresponding author: ashephidayat@yahoo.com; ashephidayat@forda-mof.org 


\section{INTRODUCTION}

Fungi belonging to the Genus Fusarium are widely distributed and could be found in soil, water, air and plants. Tropical forest is well known for its extremely rich biodiversity including fungi and other microorganisms. For example, the highly valuable Fusarium sp. found in Indonesian tropical forests has been used as inducer to accelerate agarwood production. Agarwood is a highly valuable resinous material produced by particular tree species such as Aquilaria spp. and Gyrinops spp. Previous study indicated that one genera of Fusarium, known as Fusarium sp. F092 was able to degrade chrysene under saline conditions (Hidayat, Tachibana, \& Itoh, 2012), and aliphatic fraction in crude oil (Hidayat \& Tachibana, 2012). Those results revealed that Fusarium sp. screened from nature could be utilized for many bio-prospect purposes such as bio-induction and biodegradation. Hence, microorganism collection, isolation and screening from the Indonesian tropical rain forest should be carried out soon as the declining of good tropical rain forest vegetation is clearly visible.

In general, fungi known for their decaying capabilities to wood in the forest by means of enzymatic reaction for the degradation of lignin and cellulose. Some organic pollutants were identical based on some chemical properties as compared to that of lignin and cellulose. By hypal elongation and proper secretion of enzymes, fungi were able to access, attack, degrade and mineralize xenobiotic pollutants such as phenols and chlorinated phenolic compounds, petroleum hydrocarbons, polycyclic aromatic hydrocarbons, and other substances in various matrices to innocuous products.

Environmental quality of mangrove and swamp forest ecosystems in Indonesia have been declining because the use of chemical substances in industrialization and the offshore fossil fuel refinery processes which are generating environmental pollutants (Ke, Yu, Wong, \& Tam, 2005) In many cases, environmental effects of the chemical substances have serious hazards to human health and need to be degraded after intended uses. Bioremediation and phytoremediation offers a technology to treat the organic pollutants in mangrove forest and its surrounding with a viable, low cost, and widespread use (Erdogan \& Karaca, 2011)

As an organic pollutant, the aliphatic fraction is the largest component in fossil fuels. Its removal from contaminated sites has been considered useful for evaluating the successfulness of the bioremediation program (Binazadeh, Karimi, \& Li, 2009). Many microorganisms including fungi are known to grow and utilize hydrocarbons in crude oil and derived products (Cerniglia, 1992; Juhasz \& Naidu, 2000; Thavasi, Jayalakshmi, Radhakrishnan, \& Balasubramanian, 2007; Yemashova et al., 2007; Sarma \& Sarma, 2010; Das \& Chandran, 2011). Although aliphatic hydrocarbons are easily biodegraded, but long chain and branched-chain hydrocarbons are not (Hasanuzzaman et al., 2007).

In a previous study, Fusarium sp. F092 degraded all aliphatic fractions in crude oil (Hidayat \& Tachibana, 2012), but the degradation pathways itself has not been understood. The mechanisms on how Fusarium sp. F092 could utilize aliphatic fraction in crude oil as carbon and energy sources needs to be further investigated. Degradation process is usually closely relative to the enzyme production, which could be also examined by addition of an inducer or inhibitor for a specific enzyme to the culture (Mori \& Kondo, 2002; Tsai \& Li, 2007; Mori, Nakamura, \& Kondo, 2009). The objectives of this study were: 1) to investigate the capability of Fusarium sp. F092 to degrade aliphatic compound in crude oil, n-octadecane; 2 ) to evaluate the effect of enzyme inhibitor, Piperonyl Butoxide (PB) and Silver Nitrate $\left(\mathrm{AgNO}_{3}\right)$, on the degradation of $n$-octadecane, as well as its metabolite product during the degradation process.

\section{MATERIAL AND METHOD}

\section{A. Chemicals}

n-octadecane $\quad\left(\mathrm{C}_{18} \mathrm{H}_{38}\right), \quad n$-hexadecane $\left(\mathrm{C}_{16} \mathrm{H}_{34}\right)$, agar, glucose, wakogel S-1 silica gel, 
and chemicals were obtained from Wako. Co. Ltd (Osaka, Japan). Thin layer chromatography (TLC) aluminium sheets (silica gel 60 F254, $20 \mathrm{~cm} \times 20 \mathrm{~cm}$ ) were purchased from Merck (Darmstadt, Germany). Synthetic seawater was obtained from Delphis (Osaka, Japan).

\section{B. Microorganisms}

Fusarium sp. F092 has been collected and isolated previously (Hidayat et al., 2012). Prior to use, fungi F092 were cultivated on malt extract agar (MEA) medium containing malt extract $\left(20 \mathrm{~g} \mathrm{~L}^{-1}\right)$, glucose $\left(20 \mathrm{~g} \mathrm{~L}^{-1}\right)$, agar $(20$ $\left.\mathrm{g} \mathrm{L}^{-1}\right)$, and polypeptone $\left(1 \mathrm{~g} \mathrm{~L}^{-1}\right)$ at $25^{\circ} \mathrm{C}$ for several days and then maintained at $4^{\circ} \mathrm{C}$.

\section{Degradation of $n$-octadecane}

Degradation of $n$-octadecane (initial concentration, $0.5 \mathrm{mM}$ ) was investigated in a culture liquid medium. Fusarium sp. F092 actively growing on agar were placed into each flask culture medium containing Potato Glucose (PG), potato extract $500 \mathrm{~g}$, glucose $20 \mathrm{~g}$, yeast extract $5 \mathrm{~g}$ and artificial sea water $35 \mathrm{~g}$ (perliter of $\mathrm{H}_{2} \mathrm{O}$ ). The inoculated flasks were preincubated for 7 days followed by addition of n-octadecane solubilized in dimethylformamide (DMF), T80, and water. After a fixed time (15, 30 and 60 days), the culture flask was acidified with $5 \mathrm{~mL}$ of $1 \mathrm{~N} \mathrm{HCl}$. The culture was blended at $10000 \mathrm{rpm}$ for 10 minutes and ethyl acetate was extracted 3 times $(40 \mathrm{~mL})$. The ethyl acetate extract was dried over anhydrous $\mathrm{Na}_{2} \mathrm{SO}_{4}$ and evaporated in a vacuum at $40^{\circ} \mathrm{C}$. The concentrations of compounds were quantified by gas chromatography (GC-FID Shimadzu 2014) with a TC-5 capillary column (length: $30 \mathrm{~m}$, diameter: $0.24 \mathrm{~mm}$ ). The carrier helium gas delivered at a constant rate of 1.5 $\mathrm{mL} /$ minute with a column pressure of 100 $\mathrm{Kpa}$ and interface temperature of $280^{\circ} \mathrm{C}$. The temperature program was started at $60^{\circ} \mathrm{C}$, and increased by $10^{\circ} \mathrm{C} /$ minute until the temperature of $280^{\circ} \mathrm{C}$ was achieved and maintained for 10 20 minutes at the temperature of $280^{\circ} \mathrm{C}$ to allow late eluting compounds to exit the column. The injection volume was $2 \mu \mathrm{L}$ and the injector temperature was maintained at $280^{\circ} \mathrm{C}$ (Hidayat \& Tachibana, 2013).

The effect of inhibition of monooxygenase and dioxygenase was determined as reported previously (Tsai \& Li, 2007; Mori et al., 2009). The cultures were incubated for 15 days, and the degradation was examined. The molecular structure of metabolites were also evaluated, the dried extracts were methylated with trimethylsilylation (TMS), N,O-bis-trimethylsilylacetamide $(40 \mu \mathrm{L})$, and trimethylchlorosilane $(40 \mu \mathrm{L})$ in pyridine $(80 \mu \mathrm{L})$, prior to the GC-MS analysis. The methylated sample and authentic standard were analysed by gas chromatography with a mass spectrometer (GC-MS Shimadzu QP-2010) equipped with a TC-1 column (length: $30 \mathrm{~m}$, diameter: $0.24 \mathrm{~mm}$ ) as reported by Hidayat and Tachibana (2013).

\section{Statistical Analysis}

All results are presented as means \pm the standard deviation. Data were analysed to establish differences among individual treatments by t-test using SPSS Version 15 for windows.

\section{RESULT AND DISCUSSION}

The aliphatic fraction is usually the largest component and its removal from contaminated fields has become an environmental priority and been considered useful for enhancing the recovery of the environment. Microbial degraders have been shown to attack crude oil by degrading the short-chain aliphatics and lower-molecular weight aromatic. Other compounds in crude oil such as resin and asphaltenes were more recalcitrant and with low rates of degradation (Atlas, 1981; Lal \& Khanna, 1996). Fusarium sp. F092 was isolated based on its ability to degrade chrysene under saline conditions and break down the aliphatic fraction in crude oil. However, these aliphatic degradative pathways are not yet clearly understood.

The degradation of n-octadecane was evaluated in order to know the mechanisms by which single aliphatics are broken down by 
Fusarium sp. F092 in liquid cultures. Degradation of $n$-octadecane was increased by addition of incubation time, from 15 to 30 or 60 days. At the final incubation, F092 degraded 89\% of n-octadecane (Figure 1).

\section{A. Addition: Effect of Piperonyl Butoxide (PB)}

The effect of PB addition to the Fusarium sp. F092 cultures is shown in Figure 2. Increasing the PB concentration did not promote $n$-octadecane degradation. The degradation with $0.1 \mathrm{mM}$ and $0.5 \mathrm{mM}$ was $65 \%$ and $66 \%$ after 15 days, respectively. No significant differences were found in the degradation of n-octadecane by the addition of the PB ( $\mathrm{p}<0.05)$ compared to control. PB is a cytochrome P-450 monooxygenase inhibitor (Hogdson \& Levi, 1998; Mori et al., 2009) and categorized as a group of methylenedioxyphenyl compound. $\mathrm{PB}$ inhibit the binding of $\mathrm{CO}$ mixed function oxidases to the heme group of cytochrome P-450 and thus cause the loss of the cytochrome P-450 complex (Hogdson \& Levi, 1998). Previous literatures explained that the degradation of toxic aromatic groups by cytochrome P-450 monooxygenase involved several reactions including hydroxylation at an unsubstituted position (Mori et al., 2009; Sakaki \& Munetsuna, 2010). This study showed no significant different results and indicated that degradation of $n$-octadecane by F092 occurred without involving P-450 monooxygenase.

\section{B. Addition: Effect of Silver Nitrate $\left(\mathrm{AgNO}_{3}\right)$}

To investigate the effect of $\mathrm{AgNO}_{3}$ on n-octadecane degradation, Fusarium sp. F092 was incubated in a liquid culture containing 125 mg L ${ }^{-1}$ of $n$-octadecane and two concentrations of $\mathrm{AgNO}_{3}(0.1 \mathrm{mM}$ and $0.5 \mathrm{mM})$. Comparing to the control, degradation decreased significantly at both $\mathrm{AgNO}_{3}$ concentration ( $\mathrm{p}<0.05$, Figure 2). $\mathrm{AgNO}_{3}$ is commonly used as an inhibitor of 1,2- and 2,3-dioxygenase (Aoki, 2001; Kim, Song, Kim, Ho, \& Oh, 2003). 1,2- and 2,3-dioxygenase requires $\mathrm{Fe}^{2+}$ and $\mathrm{Fe}^{3+}$ as a noniron-sulfur cofactorand two conserved histidines and tyrosines (Broderick \& O'Halloran, 1991). The inhibitor together with $\mathrm{NO}$ and $\mathrm{CN}^{-}$can bind at the vacant co-ordination site, to form a ternary complex (Bugg, 2003) Dioxygenase also contains cysteines (Kim et al., 2001), where $\mathrm{AgNO}_{3}$ acts as a cysteine inhibitor or reacts with the sulfhydryls in the protein molecule (Aoki, 2001). This result revealed that degradation of $n$-octadecane by F092 occurred by involving dioxygenase.

\section{Metabolite Product Degradation of n-octadecane}

As the result of the degradation, some of

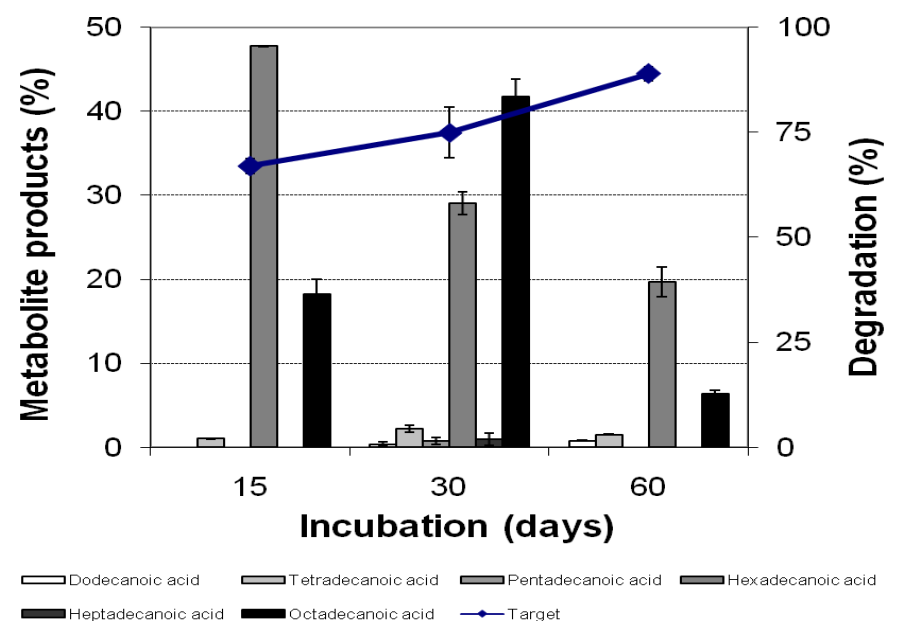

Figure 1. Degradation of n-octadecane by F092 and its metabolite products 
metabolite products were detected in control (Figure 1). We found six major metabolites that had been analysed by GC-MS and proven by trimethylsilylation, those are: 1) octadecanoic acid detected at retention time (Rt) of 19.367 and a molecular ion $\left[\mathrm{M}^{+}\right]$at $\mathrm{m} /$ z 356; 2) heptadecanoic acid having Rt of 18.458, a molecular ion $\left[\mathrm{M}^{+}\right]$at $m / ₹ 342$, and fragmentation ions at $m / z, 327\left(\mathrm{M}^{+}-\mathrm{CH}_{3}\right)$ and $\left.269\left(\mathrm{M}^{+}-\mathrm{Si}\left(\mathrm{CH}_{3}\right)_{3}\right) ; 3\right)$ hexadecanoic acid found at Rt of 17.508 , with a molecular ion $\left[\mathrm{M}^{+}\right]$at $\mathrm{m} / \mathrm{z} 328$, and fragmentation ions at $m / \mathrm{z}^{3} 313\left(\mathrm{M}^{+}\right.$ $\left.-\mathrm{CH}_{3}\right)$ and $255\left(\mathrm{M}^{+}-\mathrm{Si}\left(\mathrm{CH}_{3}\right)_{3}\right)$; 4) pentadexanoic acid had a Rt of 16.508 , a molecular ion $\left[\mathrm{M}^{+}\right]$at $\mathrm{m} / \mathrm{z} 314$, and fragmentation ions at $\mathrm{m} / \mathrm{z} 299\left(\mathrm{M}^{+}\right.$ $\left.-\mathrm{CH}_{3}\right)$ and $\left.241\left(\mathrm{M}^{+}-\mathrm{Si}\left(\mathrm{CH}_{3}\right)_{3}\right) ; 5\right)$ tetradecanoic acid with Rt of 15.467 and a molecular ion $\left[\mathrm{M}^{+}\right]$at $m / z$ 300, fragmentation ions at $m / z$. $285\left(\mathrm{M}^{+}-\mathrm{CH}_{3}\right)$ and $227\left(\mathrm{M}^{+}-\mathrm{Si}\left(\mathrm{CH}_{3}\right)_{3}\right)$; and 6) dodecanoic acid had a Rtof 13.250, a molecular ion $\left[\mathrm{M}^{+}\right]$at $m / z 272$, and fragmentation ions at $m / z 257\left(\mathrm{M}^{+}-\mathrm{CH}_{3}\right)$ and $199\left(\mathrm{M}^{+}-\mathrm{Si}\left(\mathrm{CH}_{3}\right)_{3}\right)$.

Figure 1 also shows that three of the six metabolites, hexadecanoic acid (47\%), octadecanoic acid (18\%) and tetradecanoic acid $(1 \%)$ appeared at 15 days' incubation. After that, two other metabolites were found, pentadecanoic acid $(0.7 \%)$ and dodecanoic acid $(0.3 \%)$. However at the end of the incubation, heptadecanoic and pentadecanoic acid had not been detected and the concentrations of the four other metabolites tended to decrease. This fact indicated that F092 were not only able to degrade $n$-octadecane but able to degrade metabolites products also.

The three pathways of $n$-alkanes proposed (Rehm \& Reiff, 2005; Harayama, Kishira, Kasai, \& Shutsubo, 1999), involving enzyme reactions: (i) terminal oxidation with further separated into; a) monoterminal oxidation $\left(\mathrm{RCH}_{3} \rightarrow \mathrm{RCH}_{2} \mathrm{OH} \rightarrow \mathrm{RCHO} \rightarrow \mathrm{RCOOH}\right)$, b) diterminal oxidation $\left(\mathrm{H}_{3} \mathrm{CRCH}_{3} \rightarrow\right.$ $\mathrm{H}_{3} \mathrm{CRCH}_{2} \mathrm{OH} \rightarrow \mathrm{HOCH}_{2} \mathrm{RCH}_{2} \mathrm{OH} \rightarrow$ HOOCRCOOH); (ii) subterminal oxidation $\left(\mathrm{RCH}_{2} \mathrm{CH}_{3} \rightarrow \mathrm{RCH}(\mathrm{OH}) \mathrm{CH}_{3} \rightarrow \mathrm{RC}(\mathrm{O}) \mathrm{CH}_{3}\right)$ (Rehmn \& Reiff, 1981); and (iii) degradation via alky hydroperoxides $\left(\mathrm{RCH}_{3} \rightarrow \mathrm{RCH}_{2}\right.$. $\mathrm{OOH}$ $\rightarrow \mathrm{RCO}(\mathrm{O}) \mathrm{OH} \rightarrow \mathrm{RCHO} \rightarrow \mathrm{RCOOH})$. In case of terminal and subterminal oxidation, $n$-alkane is initially attacked by hydroxylases (monooxygenases) to produce the primary or secondary alcohol. While for the degradation via akyl hydroperoxidase, the enzyme reaction that attacked n-alkane containing $\mathrm{FAD}^{+}$and $\mathrm{Cu}^{2+}$ categorized as prosthetic group (Maeng et al., 1996).

According to our study by inhibition of the P-450 monooxygenase activity, we found that

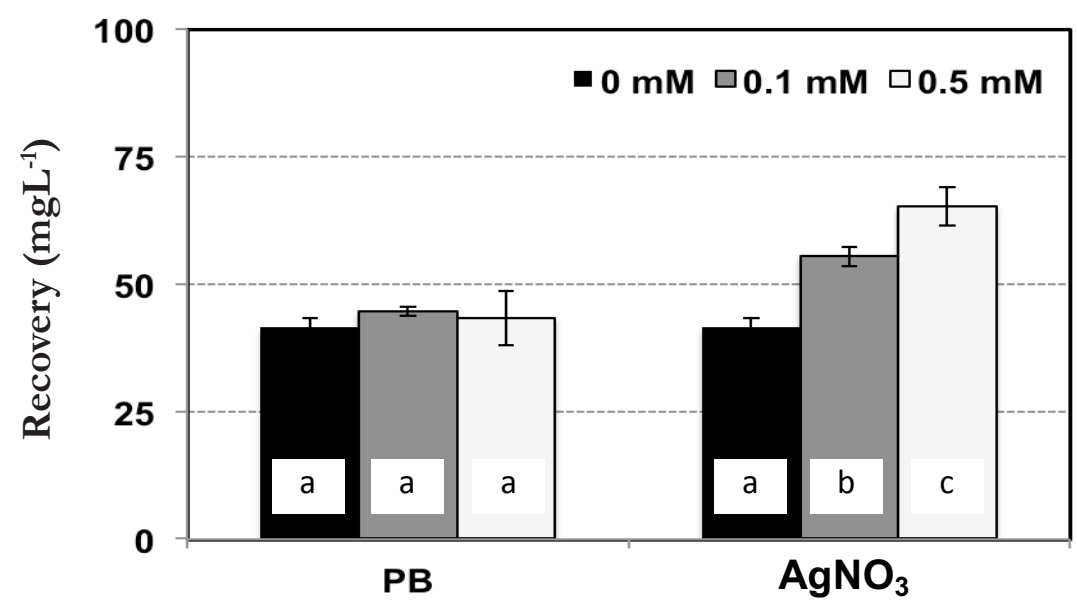

Figure 2. Effect of $\mathrm{PB}$ and $\mathrm{AgNO}_{3}$ on recovery of $n$-octadecane after degradation by F092 at 15 day's incubation. The same minor letter on each bar for each treatment is not statistically different from each other $(\mathrm{P}<0.05)$ 
was not significantly different from that of control (Figure 2). It means that enzyme P-450 monooxygenase was not involved in the enzyme reaction in the degradation of $n$-octadecane by F092, and the pathway of alkane degradation occurred without terminal or subterminal oxidation. In other way, we also did study via addition of $\mathrm{AgNO}_{3}$ to inhibit the activity of dioxygenase. The n-octadecane degradation was via alkyl hydroperoxidases, which might be mediated by a dioxygenase. The route of $n$-octadecane's degradation was initially the formation of octadecyl hydroperoxides, which were further oxidized to produce octadecanal and finally being converted to a fatty acid.

\section{CONCLUSION}

Fusarium sp. F092 was identified to have ability in degrading $n$-octadecane and the degradation process was affected by the addition of Piperonyl Butoxide (PB) and Silver Nitrate $\left(\mathrm{AgNO}_{3}\right)$. During the degradation of $n$-octadecane, some metabolite products were identified by formation of six carboxylic acid groups. The enzymatic reaction also was determined, dioxygenase was recognized as an important enzyme during the degradation process. The degradative pathway of n-octadecane by F092 was done by initially converting $n$-octadecane to form octadecyl peroxides via a dioxygenase and produced carboxylic acid.

\section{ACKNOWLEDGEMENT}

The authors are grateful to Prof. Kazutaka Itoh, Department of Applied Bioscience, Faculty of Agriculture, Ehime University-Japan for assisting in the laboratory works. We thank to editor, reviewers and my colleagues for critical reading and suggestion to improve the manuscript.

\section{REFERENCES}

Aoki, Y. (2001). Polychlorinated biphenyls, polychlorinated dibenzo-p-dioxins, and polychlorinated dibenzofurans as endocrine disrupters--what we have learned from Yusho disease. Environmental Research, 86(1), 2-11.

Atlas, R. M. (1981). Microbial degradation of petroleum hydrocarbons: an environmental perspective. Microbiological Reviews, 45(1), 180 209.

Binazadeh, M., Karimi, I. A., \& Li, Z. (2009). Fast biodegradation of long chain n-alkanes and crude oil at high concentrations with Rhodococcus sp. Ensyme and Microbial Technology, 45(3), 195-202.

Broderick, J. B., \& O’Halloran, T. V. (1991). Over production, purification, and characterization of chlorocatechol dioxygenase, a non-Heme iron dioxygenase with broad substrate tolerance. Biochemistry, 30(29), 7349-7358.

Bugg, T. D. H. (2003). Dioxygenase enzymes: catalytic mechanisms and chemical models. Tetrahedron, 59(36), 7075-7101.

Cerniglia, C. E. (1992). Biodegradation of polycyclic aromatic hydrocarbons. Biodegradation, 3, 351368.

Das, N., \& Chandran, P. (2011). Microbial degradation of petroleum hydrocarbon contaminants: An overview. Biotechnology Research International, 1-13.

Erdogan, E. E., \& Karaca, A. (2011). Bioremediation of crude oil polluted soils. Asian Journal of Biotechnology, 3(3), 206-213. doi:10.3923/ ajbkr.2011.206.213

Harayama, S., Kishira, H., Kasai, Y., \& Shutsubo, K. (1999). Petroleum biodegradation in marine environments. Journal of Molecular Microbiology and Biotechnology, 1(1), 63-70.

Hasanuzzaman, M., Ueno, A., Ito, H., Ito, Y., Yamamoto, Y., Yumoto, I., \& Okuyama, H. (2007). Degradation of long-chain n-alkanes (C36 and C40) by Pseudomonas aeruginosa strain WatG. International Biodeterioration \& Biodegradation, 59(1), 40-43. doi:10.1016/j. ibiod.2006.07.010

Hidayat, A., \& Tachibana, S. (2012). Biodegradation of aliphatic hydrocarbon in three types of crude oil by Fusarium sp. F092 under stress with artificial sea water. Journal of Environmental Science and Technology, 5(1), 64-73. doi:10.3923/ jest.2012.64.73

Hidayat, A., \& Tachibana, S. (2013). Crude oil and n-octadecane degradation under saline conditions by Fusarium sp. F092. Journal of Environmental Sciences and Technology, 6, 29-40. 
Hidayat, A., Tachibana, S., \& Itoh, K. (2012). Determination of chrysene degradation under saline conditions by Fusarium sp. F092, a fungus screened from nature. Fungal Biology, 116(6), 706-714. doi:10.1016/j. funbio.2012.04.004.

Hogdson, E., \& Levi, P. E. (1998). Interaction of piperonyl butoxide with cytochrome P450. In D. G. Jones (Ed.). Piperonyl butoxide, the insecticide synergist. (pp. 41-54). California: Academy Press.

Juhasz, A. L., \& Naidu, R. (2000). Bioremediataion of high molecular weight polycyclic aromatic hydrocarbons : a review of the microbial degradation of benzo[a]pyrene. International Biodeterioration \& Biodegradation, 45(1-2), 5788. doi:10.1016/S0964-8305(00)00052-4

Ke, L., Yu, K. S., Wong, Y. S., \& Tam, N. F. (2005). Spatial and vertical distribution of polycyclic aromatic hydrocarbons in mangrove sediments. Science Total Environment, 340(1), 177-187.

Kim, S. I., Kim, S.-J., Leem, S.-H., Oh, K.H., Kim, S., \& Park, Y., -M. (2001). Sitedirected mutagenesis of two cysteines $(155,202)$ in catechol 1,2-dioxygenase I of Acinetobacterlwofii K24. Biochemistry and Molecular Biology, 34(2), 172-175.

Kim, S. I., Song, S. Y., Kim, K. W., Ho, E. M., \&Oh, K. H. (2003). Proteomic analysis of the benzoate degradation pathway in Acinetobacter sp. KS1. Research in Microbiology, 154(10), 697-703.

Lal, B., \& Khanna, S. (1996). Degradation of crude oil by Acinetobacter calcoacetius and Alcaligenes odorans. Journal of Applied Bacteriology, 81(4), 355-362.

Maeng, J. H., Sakai, Y., Tani, Y., \& Kato, N. (1996). Isolation and characterization of a novel oxygenase that catalyzes the first step of nalkane oxidation in Acinetobacter sp. strain M-1. Journal of Bacteriology, 178(13), 36953700 .
Mori, T., \& Kondo, R. (2002). Oxidation of dibenzo-p-dioxin, dibenzofuran, biphenyl, and diphenyl ether by the white-rot fungus Phlebia lindtneri. Applied Microbiology and Biotechnology, 60(1-2), 200-205.

Mori, T., Nakamura, K., \& Kondo, R. (2009). Fungal hydroxylation of polychlorinated naphthalenes with chlorine migration by wood rotting fungi. Chemosphere, 77(9), 1230-1235. doi:10.1016/j.chemosphere.2009.08.046.

Rehm, H. J., \& Reiff, I. (2005). Mechanism and occurrence of microbial oxi-dation of long chain alkanes. Advances in Biochemical Engineering, 19, 172-215.

Sakaki, T., \& Munetsuna, E. (2010). Enzyme systems for biodegradation of polychlorinated dibenzo-p-dioxins. Applied Microbiology and Biotechnology, 88(1), 23-30. doi:10.1007/ s00253-010-2765-2.

Sarma, A., \& Sarma, H. (2010). Enhanced biodegradation of oil products by some microbial isolate supplemented with heavy metals. International Journal of Botany, 6(4), 441-448.

Thavasi, R., Jayalakshmi, R., Radhakrishnan, R., \& Balasubramanian, T. (2007). Plasmid incidence in four species of hydrocarbonoclastic bacteria isolated from oil polluted marine environment. Biotechnology, 6(3), 349-352. doi:10.3923/biotech.2007.349.352

Tsai, S. C., \& Li, Y. K. (2007). Purification and characterization of a catechol 1,2-dioxygenase from a phenol degrading Candida albicans TL3. Archives of Microbiology, 187(3), 199-206. doi:10.1007/s00203-006-0187-4

Yemashova, N. a., Murygina, V. P., Zhukov, D. V., Zakharyantz, A. a., Gladchenko, M. a., Appanna, V., \& Kalyuzhnyi, S. V. (2007). Biodeterioration of crude oil and oil derived products: A review. Reviews in Environmental Science and Biotechnology, 6(4), 315-337. doi:10.1007/s11157-006-9118-8 